\title{
The Metabolic and Hormonal Responses to Glucose Infusion in Anaesthetized Normal and Diabetic Dogs Controlled by an Artificial B-Cell
}

\author{
A. M. Albisser, B. Zinman ${ }^{1}$, E. B. Marliss ${ }^{1}$, and C. K. Botz \\ Division of Biomedical Research, Hospital for Sick Children, and ${ }^{1}$ Toronto General Hospital and the University of Toronto, \\ Toronto, Ontario, Canada
}

\begin{abstract}
Summary. The metabolic response to glucose infusion in anaesthetized normal and pancreatectomized dogs has been assessed. Normoglycaemia was achieved in the diabetic dogs with an external artificial B-cell which administered insulin into the peripheral circulation. No differences were found in the levels of blood glucose, glucagon, lactate, pyruvate and plasma non-esterified fatty acids, either in the fasting state or in response to glucose infusion. However, compared to normal animals normoglycaemic diabetic dogs had significantly elevated circulating levels of insulin and alanine at all times. Fasting levels of the same hormones and metabolites were also measured in conscious dogs. Blood pyruvate levels were higher, and plasma non-esterified fatty acid levels lower, in the anaesthetized animals. There were also minor but consistent changes in blood glucose and plasma insulin while glucagon, lactate and alanine levels were unaffected by anaesthesia. In conclusion, controlled barbiturate anaesthesia has relatively minor effects on the metabolic and hormonal status of the dog. The metabolic and hormonal response to glucose infusion in pancreatectomized dogs treated with an artificial B-cell was almost entirely normalized, except for peripheral hyperinsulinaemia and hyperalaninaemia.
\end{abstract}

Key words: Glucose, artificial pancreas, insulin, glucagon, lactate, pyruvate, alanine, free fatty acids, anaesthesia, metabolic response, insulin infusion, diabetes.

Absolute insulin deficiency produces abnormalities in the metabolism of protein, fat and carbohydrate. Subcutaneous administration of insulin improves but does not normalize these derangements, particularly with respect to blood glucose. Normoglycaemia can be restored $[1,2]$ if insulin is infused by an artifical Bcell. Under these conditions the opportunity arises for examining the concurrent concentrations of certain hormones and several intermediates of fuel metabolism during meal absorption [3, 4] and exercise $[5,6]$. In the present study, we infused glucose into normal and diabetic dogs and examined the responses of the circulating concentrations of glucose, insulin, glucagon, lactate, pyruvate, alanine and non-esterified fatty acids. Glycaemia was normalized in the diabetics using an artificial B-cell [7] which administered insulin into the peripheral circulation. In addition the effect of anaesthesia alone on the fasting concentrations of these hormones and intermediary metabolites was assessed.

\section{Materials and Methods}

\section{Animal Preparation and Blood Sampling}

Six non-obese male beagles, 1 to 2 years old and weighing $12.2 \pm$ $0.2 \mathrm{~kg}$ were fasted for $12 \mathrm{~h}$ prior to each experiment. All were studied as anaesthetized controls. Five were included in the postpancreatectomy protocols. Five other dogs weighing $12.4 \pm 0.5 \mathrm{~kg}$ were similarly fasted and served as conscious controls. Dogs were fed a weight maintaining diet $(600 \mathrm{~g} /$ day $)$ consisting of equal weights of dog chow (Master Premium Dinner, Maple Leaf Mills Ltd., Toronto, Ont.) and canned dog food (Meal Mix, Derby Pet Foods Ltd., Toronto, Ont.), given at $0900 \mathrm{~h}$. Calories were distributed as $38 \%$ carbohydrate, $33 \%$ protein and $29 \%$ fat. General anaesthesia was induced with an IV 1:1 mixture of pentobarbitone (Nembutal Sodium Injection, Abbott Laboratories, N. Chicago, IIl.) and thiopentone (Pentothal Sodium, Abbott Laboratories, Montreal, Que.) totalling $25 \mathrm{mg} / \mathrm{kg}$ body weight. Anaesthesia was maintained throughout the experiment by a slow infusion $(\approx$ $25 \mathrm{mg} / \mathrm{h}$ ) of thiopentone into the saphenous vein. The level of anaesthesia was monitored by heart and respiration rates and blood gas analysis. The flow of anaesthetic was adjusted to main- 
Table 1. Amounts of glucose and insulin infused in diabetic dogs during the baseline glucose infusion, and recovery phases of the experiments

\begin{tabular}{lcc}
\hline $\begin{array}{l}\text { Phase } \\
\text { (time) }\end{array}$ & $\begin{array}{l}\text { Glucose } \\
\mathrm{mg}\end{array}$ & $\begin{array}{l}\text { Insulin } \\
\mathrm{mU}^{\mathrm{a}}\end{array}$ \\
\hline $\begin{array}{l}\text { Baseline } \\
(-40 \rightarrow 0 \text { min })\end{array}$ & 0 & 174 \\
$\begin{array}{l}\text { Glucose infusion } \\
(0 \rightarrow 60 \text { min })\end{array}$ & 6840 & 1608 \\
$\begin{array}{l}\text { Recovery } \\
(60 \rightarrow 180 \text { min })\end{array}$ & 0 & 550 \\
\hline
\end{tabular}

${ }^{\mathrm{a}} 1 \mathrm{mU}=41 \mathrm{ng}$ insulin

tain these variables close to normal. To compensate for blood loss $0.154 \mathrm{~mol} / 1$ saline and thiopentone were infused at about $1.5 \mathrm{ml} /$ min throughout the experiment. Body temperature was monitored, and maintained by external heat applied with a heating lamp or electric blanket. A dual-lumen catheter (Abjad Industries, Toronto, Ont.) was placed in a superficial jugular vein and provided blood diluted $1: 1$ with $0.154 \mathrm{~mol} / 1$ saline containing $25 \mathrm{U} / \mathrm{ml}$ heparin for continuous glucose monitoring. Another catheter was similarly placed to permit the sampling of undiluted blood for the later determination of hormones and intermediary metabolites. Blood $(1.5 \mathrm{ml})$ from the second jugular vein was collected at -40 , $-10,0,5,10,15,30,45,60,75,90,120,150$ and $180 \mathrm{~min}$ directly into $1.5 \mathrm{ml}$ centrifuge tubes containing $0.15 \mathrm{ml}$ heparin for the later determination of insulin. At $-30,0,30,60,90,120$ and $180 \mathrm{~min}$ blood $(2 \mathrm{ml})$ was distributed into $5 \mathrm{ml}$ tubes containing a total of $0.2 \mathrm{ml}$ of a 1:1 mixture of aprotinin (Trasylol $10000 \mathrm{KIU} /$ ml, FBA Pharmaceuticals Ltd., Pte. Claire, Que.) and EDTA (24 $\mathrm{mg} / \mathrm{ml}$ ethylene-diamine-tetra-acetic-acid in double distilled water, BDH Chemicals, Poole, England) for the later estimation of glucagon and non-esterified fatty acids (NEFA). At the same times blood was taken into capillary tubes for hematocrit determination. At 0,60 and $180 \mathrm{~min}$ blood $(2 \mathrm{ml})$ was collected into chilled tubes containing perchloric acid (PCA, 10\% W/V), in a volume equal to that of blood, for the later determination of lactate, pyruvate and alanine concentrations. The total volume of blood in these samples was $41 \mathrm{ml}$. Continuous glucose estimation required a further $3 \mathrm{ml} / \mathrm{h}$ whole blood. At time 0 glucose challenge was begun.

In the conscious control animals samples were drawn from an external jugular vein at 0800 and 0900 just prior to feeding. Minimal stress was induced by the use of a chronic exteriorized indwelling silastic catheter. Blood was distributed as above into tubes containing heparin, EDTA/aprotinin, or cold perchloric acid.

Blood was collected on ice and centrifuged with minimal delay at $4{ }^{\circ} \mathrm{C}$ and the supernatants frozen at $-20^{\circ} \mathrm{C}$ until assay.

\section{Analytical Methods}

The continuous blood glucose analyzer was calibrated against a Beckman glucose analyzer (Beckman Instruments, Fullerton, Cal.) to read equivalent plasma glucose concentration as previously described [8]. Total time delay was $2 \mathrm{~min}$.

Plasma insulin was determined using an anti-porcine insulin anti-serum (from Dr. Peter Wright, Minneapolis, Minn.), a dextran coated charcoal separation of free from bound hormone [9], and a pork insulin standard (Novo Research Institute, Copenhagen, Denmark). Glucagon was determined on unextracted plasma with antiserum $30 \mathrm{~K}$ (obtained from Dr. R. H. Unger, Dallas,
Tex.), purified pork glucagon standard, and ${ }^{125}$ I-labelled pork glucagon (Novo Research Institute, Copenhagen, Denmark) and the same dextran coated charcoal separation technique. The precisions of the insulin and glucagon assays were approximately \pm $10 \%$ over the range 0.125 to $4 \mathrm{ng} / \mathrm{ml}$ and 20 to $2000 \mathrm{pg} / \mathrm{ml}$ respectively. Lactate, pyruvate and alanine were analyzed by microfluorometric adaptations of standard enzymic methods [10] employing an Aminco Fluoro-microphotometer (American Instrument Co., Division of Travenol Laboratories, Silver Springs, Md.). NEFA levels were estimated by a radio-chemical microtechnique [11].

Porcine neutral crystalline zinc insulin (Connaught Laboratories, Ltd., Toronto, Ont.) for infusion was diluted in 0.154 $\mathrm{mol} / 1$ saline to $17 \mathrm{mU} / \mathrm{ml}$. No loss of insulin was detectable in the absence of added protein. The precision of the saline-insulin dilution was verified by immunoassay as was the immunologic identity of the infused insulin and the standards in the assay conditions used (data not shown).

\section{Blood Glucose Control}

Glycaemic regulation in the diabetic dogs was obtained with an artificial B-cell which used the same continuous glucose analyzer as outlined above [8], and in which the chosen algorithms and constants $[12,13]$ were previously defined. Insulin was infused into a saphenous vein at a rate responsive on a minute-by-minute basis to both the blood glucose level and its rate of change. Insulin infusion was with a pulsatile pump (Lambda Pump, Harvard Instruments Ltd., Millis, Mass.).

\section{Glucose Infusions}

Glucose infusions were for $60 \mathrm{~min}$ into the saphenous vein at a rate of $10 \mathrm{mg} / \mathrm{kg} / \mathrm{min}$. All challenges started after a $40 \mathrm{~min}$ baseline period of constant glycaemia and were followed by a $120 \mathrm{~min}$ recovery period. A precalibrated channel of the multi-channel peristaltic pump in the glucose analyzer was used for glucose infusion.

\section{Pancreatectomy and Management of Diabetes}

Diabetes was induced by surgical removal of the pancreas $[7,13]$. Subcutaneous injection of daily doses of equal amounts of NPH and crystalline zinc porcine insulin (Connaught Laboratories Ltd., Toronto, Ont.) were given between experiments. The dose of 18 to $24 \mathrm{U}$ insulin was based on fasting and $2 \mathrm{~h}$ postprandial blood glucose levels, determined 5 times weekly. A total of 12-14 capsules of exocrine pancreatic enzyme supplements (Cotazym, Organon Ltd., Montreal, Que.) was given with meals. All dogs maintained their presurgical weights $( \pm 1 \mathrm{~kg})$ with this treatment and bowel function was not different from normal dogs.

On the day prior to an experiment the diabetic animals were fed and injected at 0900 and $1700 \mathrm{~h}$. At each time they were given half the usual meal and half the usual total subcutaneous dose of insulin. Intermediate acting insulin was not given. Meals not finished by $2000 \mathrm{~h}$ were removed. In all cases on the morning of the experiment the animals were hyperglycaemic $(300-400 \mathrm{mg} /$ $\mathrm{dl}$ ), suggesting that little residual insulin was present. Concurrent plasma insulin levels were less than $0.08 \mathrm{ng} / \mathrm{ml}$. Normoglycaemia was restored over $1-3 \mathrm{~h}$ by a combination of continuous intravenous infusion and boluses of 0.5 to $1.0 \mathrm{U}$ insulin, and maintained for at least $40 \mathrm{~min}$ prior to glucose challenge. During the latter baseline period insulin was given at a relatively constant basal rate by the artificial B-cell. The amounts of glucose and insulin infused in the diabetic dogs during the baseline, glucose infusion, and recovery periods are summarized in Table 1 . 
Table 2. Fasting hormone and metabolite levels in conscious normal and anaesthetized diabetic dogs

\begin{tabular}{|c|c|c|c|c|c|c|c|c|}
\hline & & $\begin{array}{l}\text { Plasma } \\
\text { glucose } \\
\mathrm{mg} / \mathrm{dl}\end{array}$ & $\begin{array}{l}\text { Plasma } \\
\text { insulin } \\
\mathrm{ng} / \mathrm{ml}\end{array}$ & $\begin{array}{l}\text { Plasma } \\
\text { glucagon } \\
\mathrm{pg} / \mathrm{ml}\end{array}$ & $\begin{array}{l}\text { Blood } \\
\text { lactate } \\
\mu \mathrm{mol} / 1\end{array}$ & $\begin{array}{l}\text { Blood } \\
\text { pyruvate } \\
\mu \mathrm{mol} / 1\end{array}$ & $\begin{array}{l}\text { Blood } \\
\text { alanine } \\
\text { umol/1 }\end{array}$ & $\begin{array}{l}\text { Plasma } \\
\text { NEFA } \\
\mu \mathrm{mol} / 1\end{array}$ \\
\hline $\begin{array}{l}\text { Conscious } \\
\text { normals } \\
\text { (A) }\end{array}$ & $\begin{array}{l}(\mathrm{n})^{\mathrm{a}} \\
\text { mean } \\
\mathrm{SEM} \\
\max \\
\min \end{array}$ & $\begin{array}{l}(15) \\
90 \\
\pm 2 \\
105 \\
76\end{array}$ & $\begin{array}{l}(14) \\
0.42 \\
\pm 0.02 \\
0.59 \\
0.30\end{array}$ & $\begin{array}{l}(13) \\
80 \\
\pm 12 \\
163 \\
29\end{array}$ & $\begin{array}{l}(13) \\
744 \\
\pm 72 \\
1236 \\
412\end{array}$ & $\begin{array}{l}(13) \\
49 \\
\pm 6 \\
103 \\
22\end{array}$ & $\begin{array}{l}(13) \\
295 \\
\pm 29 \\
484 \\
125\end{array}$ & $\begin{array}{l}(13) \\
758 \\
\pm 75 \\
1157 \\
306\end{array}$ \\
\hline $\begin{array}{l}\text { Anaesthetized } \\
\text { normals } \\
\text { (B) }\end{array}$ & $\begin{array}{l}(\mathrm{n}) \\
\text { mean } \\
\text { SEM } \\
\max \\
\min \end{array}$ & $\begin{array}{l}(16) \\
98 \\
\pm 2 \\
113 \\
85\end{array}$ & $\begin{array}{l}(16) \\
0.33 \\
\pm 0.03 \\
0.49 \\
0.12\end{array}$ & $\begin{array}{l}(11) \\
54 \\
\pm 5 \\
89 \\
33\end{array}$ & $\begin{array}{l}(12) \\
873 \\
\pm 77 \\
1273 \\
417\end{array}$ & $\begin{array}{l}(12) \\
81 \\
\pm 10 \\
152 \\
39\end{array}$ & $\begin{array}{l}(12) \\
281 \\
\pm 25 \\
457 \\
156\end{array}$ & $\begin{array}{l}(12) \\
550 \\
\pm 63 \\
982 \\
287\end{array}$ \\
\hline $\begin{array}{l}\text { Anaesthetized } \\
\text { diabetics } \\
\text { (C) }\end{array}$ & $\begin{array}{l}(\mathrm{n}) \\
\text { mean } \\
\mathrm{SEM} \\
\max \\
\min \end{array}$ & $\begin{array}{l}(12) \\
101 \\
\pm 3 \\
116 \\
90\end{array}$ & $\begin{array}{l}(11) \\
0.53 \\
\pm 0.03 \\
0.71 \\
0.31\end{array}$ & $\begin{array}{l}(12) \\
60 \\
\pm 9 \\
134 \\
26\end{array}$ & $\begin{array}{l}(12) \\
990 \\
\pm 216 \\
2279 \\
318\end{array}$ & $\begin{array}{l}(12) \\
117 \\
\pm 19 \\
224 \\
42\end{array}$ & $\begin{array}{l}(12) \\
732 \\
\pm 111 \\
1504 \\
415\end{array}$ & $\begin{array}{l}(12) \\
606 \\
\pm 78 \\
1098 \\
249\end{array}$ \\
\hline $\begin{array}{l}2 \text { tailed } t \text {-tests } \\
\text { B vs A } \\
\text { C vs B }\end{array}$ & $\begin{array}{l}\mathrm{p} \\
\mathrm{p}\end{array}$ & $\begin{array}{l}* * * * \\
\text { NS }\end{array}$ & $\begin{array}{l}* \\
* * * * *\end{array}$ & $\begin{array}{l}\text { NS } \\
\text { NS }\end{array}$ & $\begin{array}{l}\text { NS } \\
\text { NS }\end{array}$ & $\begin{array}{l}* \\
\text { NS }\end{array}$ & $\begin{array}{l}\text { NS } \\
*\end{array}$ & $\begin{array}{l}* \\
\text { NS }\end{array}$ \\
\hline
\end{tabular}

a Is the number of experiments

${ }^{b}$ Levels of significance: * denotes $p<0.05-* *$ denotes $p<0.01-* * *$ denotes $p<0.005-$ NS denotes $p>0.05$

Statistical comparisons were made using the F-test for homogeneity of variances at the $5 \%$ level of significance, and then the unpaired, or where appropriate the paired, $t$-test to examine the significance of differences in, or changes from, the fasting levels in each animal.

\section{Results}

\section{Fasting Levels}

Fasting glucose, insulin, glucagon, lactate, pyruvate, alanine and NEFA levels are presented in Table 2.

The fasting glucose levels in the anaesthetized normal dogs were $8 \mathrm{mg} / \mathrm{dl}$ higher than those in the conscious normal group $(\mathrm{p}<0.005)$, blood pyruvate levels were $30 \mu \mathrm{mol} / 1$ higher $(\mathrm{p}<0.02)$, while insulin was $0.08 \mathrm{ng} / \mathrm{ml}$ lower $(\mathrm{p}<0.05)$, and plasma NEFA were lower by $200 \mu \mathrm{mol} / 1(\mathrm{p}<0.05)$. Plasma glucagon, blood lactate, and blood alanine levels were unaltered by anaesthesia.

The fasting levels of corresponding variables in the anaesthetized diabetic dogs showed two major changes compared to anaesthetized normal dogs: plasma insulin levels were $0.2 \mathrm{ng} / \mathrm{ml}$ higher $(p<0.005)$ while alanine levels were significantly and markedly elevated in the diabetic animals $(p<0.05)$. Glucose, glucagon, lactate, pyruvate and NEFA levels were unchanged.

\section{Response to Glucose Infusion}

Changes from fasting levels in blood lactate, pyruvate and alanine are shown in Table 3 for the normal and diabetic dogs. The data represent the mean increments from fasting observed 60 and 180 min after commencement of the $60 \mathrm{~min}$ glucose infusion. An apparent initial rise at $60 \mathrm{~min}$ and a subsequent fall at $180 \mathrm{~min}$ in both the lactate and pyruvate levels were not statistically significant, due mainly to large interand intra-individual differences in both groups of anaesthetized animals. Alanine was not affected by the glucose infusion in the normals but showed a gradual decline in the diabetics which was significant at $180 \mathrm{~min}(\mathrm{p}=0.025)$.

The glycaemic response (Fig. 1) to glucose infusion was similar in the normal and diabetic animals increasing to plateaus of $170 \pm 8 \mathrm{mg} / \mathrm{dl}$ and $155 \pm$ $8 \mathrm{mg} / \mathrm{dl}$ respectively at $30 \mathrm{~min}$, and returning to baseline values 15 min after the infusion was stopped. Glucose concentration was significantly lower in the diabetics only at $30 \mathrm{~min}(\mathrm{p}=0.025)$. Plasma insulin was elevated in the diabetic animals on the artificial B-cell at all times (Fig. 2). The transient decline in glucagon (Fig. 3) which occurred in both groups was significant at 30 and $60 \mathrm{~min}$. Plasma NEFA concentrations (Fig. 4) were significantly below fasting levels at 30,60 and $90 \mathrm{~min}(\mathrm{p}<0.01)$, 
Table 3. Increments from fasting in blood metabolite levels with glucose infusion in anaesthetized normal and diabetic dogs

\begin{tabular}{|c|c|c|c|c|c|c|c|}
\hline & \multirow[b]{2}{*}{$\min$} & \multicolumn{2}{|c|}{$\begin{array}{l}\Delta^{\mathrm{b} L a c t a t e} \\
\mu \mathrm{mol} / 1\end{array}$} & \multicolumn{2}{|c|}{$\begin{array}{l}\Delta \text { Pyruvate } \\
\mu \mathrm{mol} / 1\end{array}$} & \multicolumn{2}{|c|}{$\begin{array}{l}\Delta \text { Alanine } \\
\mu \mathrm{mol} / 1\end{array}$} \\
\hline & & 60 & 180 & 60 & 180 & 60 & 180 \\
\hline $\begin{array}{l}\text { Anaesthetized } \\
\text { normals } \\
\text { (A) }\end{array}$ & $\begin{array}{l}(\mathrm{n})^{\mathrm{a}} \\
\text { mean } \\
\mathrm{SEM} \\
\max \\
\min \end{array}$ & $\begin{array}{l}(12) \\
+271 \\
\pm 151 \\
+1303 \\
-420\end{array}$ & $\begin{array}{l}(12) \\
-91 \\
\pm 98 \\
+565 \\
-652\end{array}$ & $\begin{array}{l}(12) \\
+15 \\
\pm 11 \\
+77 \\
-70\end{array}$ & $\begin{array}{l}(12) \\
0 \\
\pm 9 \\
+52 \\
-61\end{array}$ & $\begin{array}{l}(12) \\
-14 \\
\pm 24 \\
+146 \\
-158\end{array}$ & $\begin{array}{l}(12) \\
-42 \\
\pm 32 \\
+126 \\
-231\end{array}$ \\
\hline $\begin{array}{l}\text { Anaesthetized } \\
\text { diabetics } \\
\text { (B) }\end{array}$ & $\begin{array}{l}(\mathrm{n}) \\
\text { mean } \\
\text { SEM } \\
\max \\
\min \end{array}$ & $\begin{array}{l}(12) \\
+314 \\
\pm 203 \\
+1886 \\
-751\end{array}$ & $\begin{array}{l}(12) \\
-180 \\
\pm 204 \\
+1208 \\
-1267\end{array}$ & $\begin{array}{l}(12) \\
+32 \\
\pm 17 \\
+124 \\
-55\end{array}$ & $\begin{array}{l}(12) \\
-29 \\
\pm 17 \\
+97 \\
-122\end{array}$ & $\begin{array}{l}(12) \\
-105 \\
\pm 69 \\
+222 \\
-637\end{array}$ & $\begin{array}{l}(12) \\
-245 \\
\pm 93 \\
+274 \\
-867\end{array}$ \\
\hline $\begin{array}{l}\text { 2-tailed t-test } \\
\text { A vs B }\end{array}$ & $\mathrm{p}$ & $N S^{c}$ & NS & NS & NS & NS & NS \\
\hline
\end{tabular}

a Is the number of observations

b $\Delta$ denotes change

c NS denotes $\mathrm{p}>0.05$

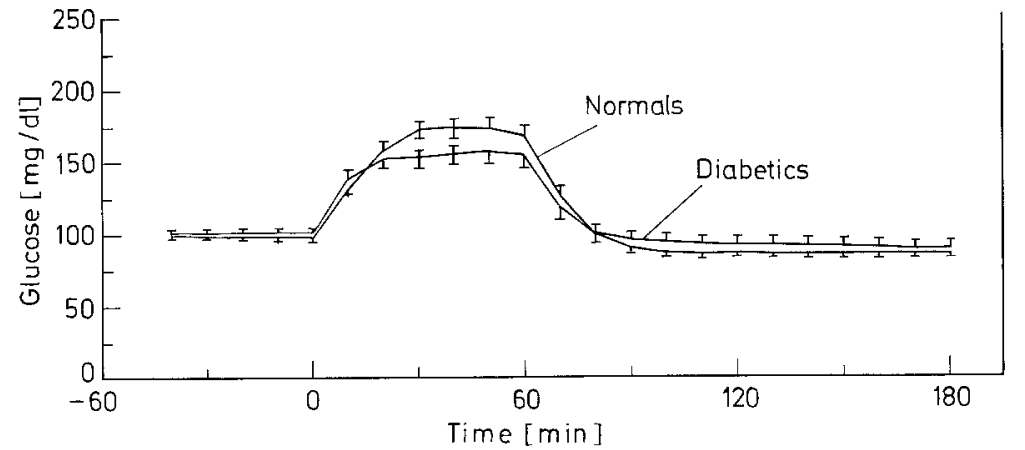

Fig. 1. Mean \pm SEM of plasma glucose concentrations. Anaesthetized normal and pancreatectomized dogs before, during and after a $60 \mathrm{~min}$ glucose infusion of $10 \mathrm{mg} / \mathrm{kg} / \mathrm{min}$ started at time 0 . Blood glucose was controlled in the diabetic animals using an artificial B-cell and was significantly lower in the diabetics only at $30 \mathrm{~min}(\mathrm{p}<0.05)$ and returned to pre-infusion concentrations at $180 \mathrm{~min}$. There were no significant differences at any time between the two groups in glucagon and NEFA levels.

\section{Discussion}

The present study was undertaken to examine the hormonal and metabolic response to glucose infusion in the diabetic dog when controlled by an artificial Bcell, as compared to sex and weight matched normal dogs. Since the glucose challenge was performed in anaesthetized dogs we measured the effect of barbiturate anaesthesia on the fasting levels of all the hormones and intermediary metabolites studied. Anaesthesia alone resulted in a small but significant increase in glucose and pyruvate while insulin and NEFA showed small decreases. Lactate, alanine and glucagon were unaffected by anaesthesia. Thus the hormones and metabolites measured do not reflect any major physiological alteration occurring with anaesthesia in normal fasting dogs.

The fasting levels of glucose, lactate, pyruvate, NEFA and glucagon in the anaesthetized diabetic dogs receiving insulin by the artificial B-cell were similar to anaesthetized normal animals. However, the peripheral insulin and alanine concentrations were significantly elevated. This observation that the attainment of normoglycaemia with the artificial Bcell results in peripheral hyperinsulinaemia has previously been documented in dogs [12-14] and man [15], and is at least in part related to the peripheral venous route of insulin administration. In contrast portal insulin infusion in the anaesthetized [16] and conscious [17] diabetic dog normalized blood glucose without peripheral hyperinsulinaemia both in the fasting state and during glucose infusion. Whether 

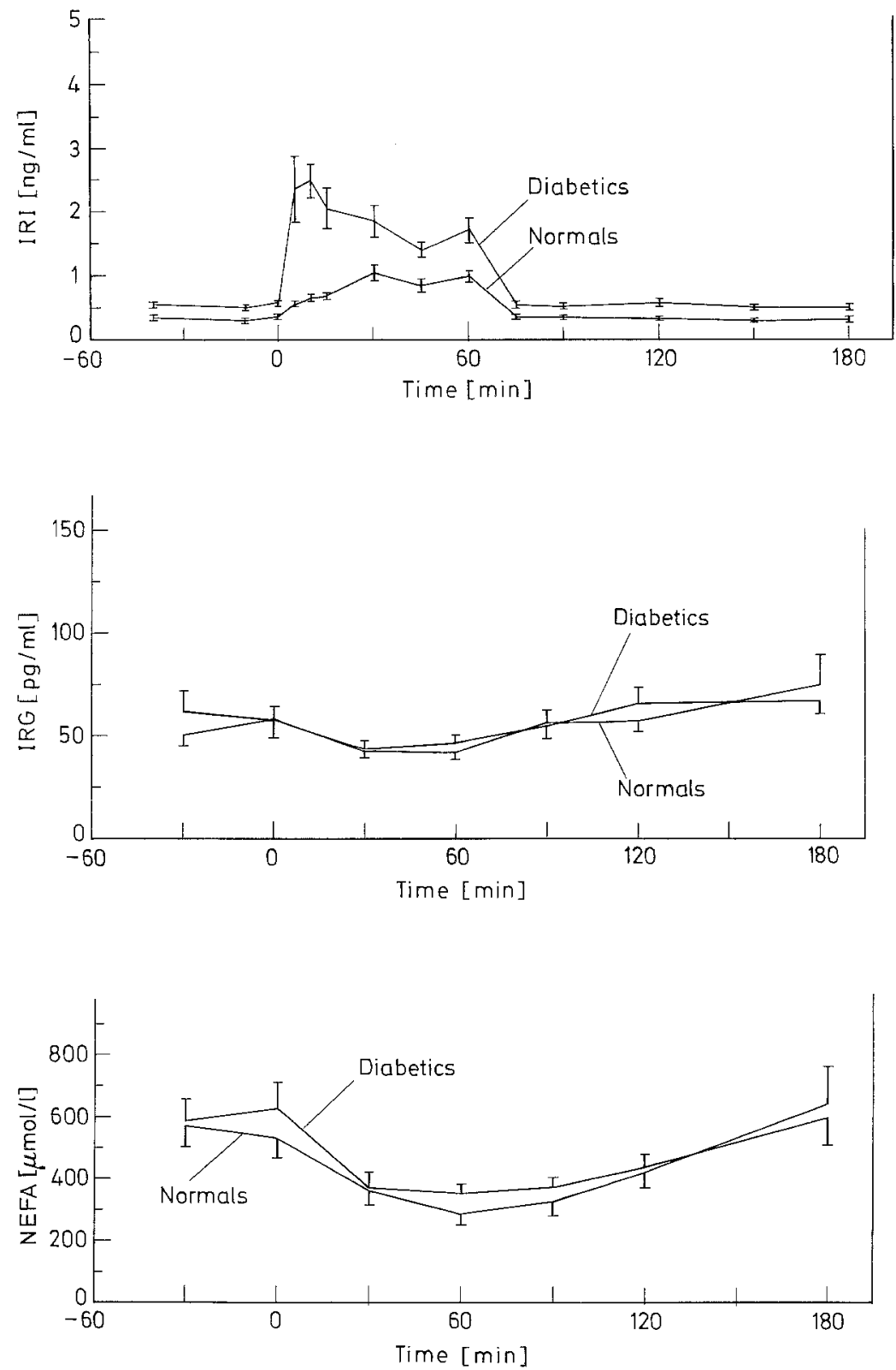

Fig. 2. Mean \pm SEM of plasma insulin (IRI) concentrations. Anaesthetized normal and pancreatectomized dogs before, during and after a $60 \mathrm{~min}$ glucose infusion of $10 \mathrm{mg} / \mathrm{kg} / \mathrm{min}$ started at time 0 . Plasma insulin in the diabetics was significantly higher than in the controls at all times $(p<0.05)$
Fig. 3. Mean \pm SEM of plasma glucagon (IRG) concentration. Anaesthetized normal and diabetic dogs before during and after a $60 \mathrm{~min}$ glucose infusion of $10 \mathrm{mg} / \mathrm{kg} / \mathrm{min}$ started at time 0 . Decrements from the fasting glucagon levels were significant $(\mathrm{p}<0.05)$ at 30 and $60 \mathrm{~min}$ in the pancreatectomized but not in the normal dogs
Fig. 4. Mean \pm SEM of plasma non-esterified fatty acids (NEFA) concentrations. Anaesthetized normal and diabetic dogs before, during and after a $60 \mathrm{~min}$ glucose infusion of $10 \mathrm{mg} / \mathrm{kg} / \mathrm{min}$ started at time 0 . Decrements from the fasting plasma NEFA levels were significant $(p<0.01)$ at $30,60,90$ and $120 \mathrm{~min}$ in both the diabetic and normal dogs the normoglycaemia so produced reflects an abnormal balance in glucose turnover due to high peripheral or low hepatic insulin levels is not clear. That hepatic metabolism is not entirely normalized is suggested by the elevated alanine concentrations.

Glucose production in the post-absorptive state is primarily from hepatic glycogenolysis and gluconeogenesis. In diabetics gluconeogenesis is accelerated as a result of insulin deficiency [18]. Alanine, pyruvate and glycerol are important gluconeogenic precursors and their rate of hepatic extraction has been shown to be accelerated in insulin deficiency $[19,20]$. It is thus surprising that in the present study alanine levels were elevated two fold, perhaps reflecting a blocking effect of the hyperinsulinaemia on the liver of these dogs. Mild but persistent hyperalaninaemia $(560 \pm 66 \mu \mathrm{mol} / 1)$ was also observed in diabetic dogs infused chronically with adequate peripheral insulin to maintain post-absorptive normoglycaemia (unpublished observations). The precise dynamics of these observations could be elucidated by measuring alanine turnover. It is of interest that pyruvate was also elevated although this was not statistically significant.

The anaesthetized normal and diabetic animals showed remarkably similar metabolic responses to glucose infusion. The increase in blood glucose occurred rapidly reaching a plateau at $30 \mathrm{~min}$ and 
quickly returning to baseline with cessation of the infusion. The fall in NEFA levels reflected the rise in insulin concentration, the antilipolytic effects of which lead to the inhibition of NEFA mobilization from adipose tissue. It is noteworthy that anaesthesia in normal dogs lowers both insulin and NEFA levels, a situation which clearly implies increased NEFA utilization. In spite of the mild $(0.2 \mathrm{ng} / \mathrm{ml})$ hyperinsulinaemia in the diabetic dogs there were no differences in the fasting plasma NEFA levels in the anaesthetized animals. Whether this is the result of reduced lipolysis and/or increased utilization is not clear. The fasting lactate, pyruvate, and alanine concentrations varied considerably in normal and diabetic anaesthetized dogs before the glucose infusion and the results are presented as increments from fasting values. Although lactate and pyruvate increased while alanine decreased in the normal and diabetic dogs these changes were not significant because of large inter-individual variability. Alanine concentration continued to decline in the post infusion period and reached significantly lower levels $(p=0.025)$ at $180 \mathrm{~min}$. The diabetic dogs were hyperglycaemic and underinsulinized prior to the start of the experiment. Under these conditions, favourable for gluconeogenesis, alanine production must have been accelerated particularly in view of the concurrent hyperalaninaemia. With the restoration of normoglycaemia by peripheral insulin infusion, gluconeogenesis was rapidly reduced but the accelerated alanine production apparently required several hours to subside. Alternately the liver of the dog may be exquisitely sensitive to insulin so that alanine uptake was reduced. The final alanine levels reached however were above normal and similar to those in fasting diabetic animals made normoglycaemic by long term peripheral insulin infusions, as mentioned above.

The metabolic response to the glucose infusion was in general similar in the normal and diabetic animals but the peripheral insulin concentrations obtained with the artificial B-cell were $2-3 \times$ higher. As discussed above this must in great part be related to the peripheral route of insulin administration.

Although in the pancreatectomized dogs the pancreatic source of glucagon had been removed fasting glucagon concentrations were similar to the normal dogs and decreased in similar fashion with glucose infusion. This observation is consistent with other studies [21-23] which indicate that nonpancreatic glucagon in the dog is immunologically and biologically similar to pancreatic glucagon, and responds in a similar physiological manner.

In summary the present study demonstrates that barbiturate anaesthesia did not cause major hor- monal or metabolic disturbance. The metabolic and hormonal response to glucose infusion in diabetic dogs controlled by the artificial B-cell was almost entirely normalized, except for peripheral hyperinsulinaemia and hyperalaninaemia.

Acknowledgements. This study was conducted as a project in the artificial pancreas programme at The Hospital for Sick Children in Toronto and benefited in part from the support provided by grants from The Juvenile Diabetes Foundation, The Medical Research Council of Canada, and a negotiated contract from The National Institutes of Health. The authors are grateful for the advice given by the members of the Divisions of Surgical Research and Animal Care at The Hospital for Sick Children, and the staff of the Hormone and Metabolic Laboratory at The University of Toronto. We thank Ms. I. Gibson for typing the manuscript.

\section{References}

1. Albisser AM, Leibel BS, Ewart TG, Davidovac Z, Botz CK, Zingg W, Schipper H, Gander R (1974) Clinical control of diabetes by the artificial pancreas. Diabetes $23: 397-404$

2. Marliss EB, Murray FT, Stokes EF, Zinman B, Nakhooda AF, Denoga A, Leibel BS, Zingg W, Albisser AM (1977) Normalisation of glycemia in diabetics during meals with insulin and glucagon delivery by the artificial pancreas. Diabetes 26 : 663-672

3. Zinman B, Stokes EF, Albisser AM, Hanna AK, Minuk HL, Stein AN, Leibel BS, Marliss EB (1979) The metabolic response to glycemic control by the artificial pancreas in diabetic man. Metabolism 28:511-518

4. Noy G (1979) Metabolic effects of glucose clamping at normal and hyperglycemic levels. Symposium on "Carbohydrate Metabolism: Quantitative Physiology and Mathematical Modeling", Padova

5. Zinman B, Murray FT, Vranic M, Albisser AM, Leibel BS, McClean PA, Marliss EB (1977) Glucoregulation during moderate exercise in insulin treated diabetics. J Clin Endocrinol Metab 45:641-652

6. Murray FT, Zinman B, McClean PA, Denoga A, Albisser AM, Leibel BS, Nakhooda AF, Zamel N, Marliss EB (1977) The metabolic response to moderate exercise in diabetic man receiving intravenous and subcutaneous insulin. J Clin Endocrinol Metab 44 : 708-720

7. Albisser AM, Leibel BS, Ewart TG, Davidovac Z, Botz CK, Zingg W (1974) An artificial endocrine pancreas. Diabetes 23:389-396

8. Albisser AM, Ellman J, Hanna A, Goriya Y, Minuk H (1978) Continuous blood glucose analysis in vitro and in vivo. Diabetologia 15:303-308

9. Herbert V, Law KD, Gottlieb CW, Bleicher SJ (1974) Coated charcoal immunoassay of insulin. J Clin Endocrinol Metab 39: 1090

10. Girard JR, Cuendet GS, Marliss EB, Kervran A, Rieurort M, Assan R (1973) Fuels, hormones and liver metabolism at term and during the early postnatal period in the rat. $\mathrm{J}$ Clin Invest $52: 3190-3200$

11. Ho RJ (1970) Radiochemical assay of long-chain fatty acids using ${ }^{63} \mathrm{Ni}$ as a tracer. Anal Biochem $36: 105-113$

12. Botz CK, Marliss EB, Albisser AM (1979) Blood glucose regulation using closed- and open-loop insulin delivery systems. II. Peripheral primed square waves. Diabetologia 17:45-49

13. Botz CK, Albisser AM, Leibel BS, Zingg W, Gander RE (1976) Comparison of peripheral and portal routes of insulin 
infusion by a computer controlled insulin infusion system (artificial endocrine pancreas). Diabetes 25:691-700

14. Goriya Y, Bahoric A, Marliss EB, Zinman B, Albisser AM (1979) Glycemic regulation using a programmed insulin delivery device. III. Long term studies. Diabetes 28:558-564

15. Hanna AK, Zinman B, Nakhooda AF, Minuk HL, Stokes EF, Albisser AM, Leibel BS, Marliss EB (in press) Insulin, glucagon and amino acids during glycemic control by the artificial pancreas in diabetic man. Metabolism

16. Albisser AM, Botz CK, Leibel BS (1979) Blood glucose regulation using an open-loop insulin delivery system in pancreatectomized dogs given glucose infusions. I. Portal square waves. Diabetologia 16:129-133

17. Cherrington AD, Vranic M (1974) Effect of interaction between insulin and glucagon on glucose turnover and FFA concentration in normal and depancreatized dogs. Metabolism 23:729-744

18. Cherrington AD, Lacy WW, Chiasson JL (1978) Effect of glucagon on glucose production during insulin deficiency in the dog. J Clin Invest 59:664-677

19. Chiasson JL, Liljenquist JE, Finger FE, Lacy WW (1976) Differential sensitivity of glycogenolysis and gluconeogenesis to insulin infusions in dogs. Diabetes $25: 283-291$
20. Felig P, Wahren J, Sherwin R, Palaiologos G (1977) Amino acid and protein metabolism in diabetes mellitus. Arch Intern Med 137:507-513

21. Cherrington AD, Kawamori R, Pek S, Vranic M (1974) Arginine infusion in dogs. Model for the roles of insulin and glucagon in regulating glucose turnover and free fatty acid levels. Diabetes 23:805-815

22. Sasaki H, Rubalcava B, Baetens D, Blazquez C, Srikant B, Orci L, Unger RH (1975) Identification of glucagon in the gastro-intestinal tract. J Clin Invest 56:135-145

23. Lefebvre PJ, Luyckx AS (1978) Glucose and insulin in the regulation of glucagon release from the isolated perfused dog stomach. Endocrinology $103: 1579-1582$

Received: June 4, 1979 ,

and in revised form: November 27, 1979

Dr. A. M. Albisser

Division of Biomedical Research

Hospital for Sick Children

555 University Avenue

Toronto M5G 1X8

Canada 